\title{
Metabolic syndrome and smoking are independent risk factors of male idiopathic infertility
}

Charlotte Dupont $^{1 *+}$, Céline Faure ${ }^{2 \dagger}$, Frederic Daoud ${ }^{2}$, Benoit Gautier ${ }^{2}$, Sébastien Czernichow ${ }^{3,4}$, Rachel Lévy ${ }^{1}$ and the ALIFERT collaborative group

\begin{abstract}
Background: Overweight and obesity are known to impact male fertility and are commonly associated with abdominal obesity and metabolic disorders. The association between abdominal obesity or metabolic syndrome with male reproduction has not been fully investigated. Moreover, many factors may interfere with the evaluation of the impact of metabolic syndrome on male fertility. Thus, tobacco is known to alter the spermatic parameters and phenomena linking smoking with metabolic syndrome are therefore complex. The main objective of this study has been to investigate the potential association of metabolic syndrome with male idiopathic infertility given smoking status.
\end{abstract}

Materiel and methods: The data of this study concerned infertile $(n=96)$ and fertile $(n=100)$ men under 45 years of age who have been recruited in the ALIFERT case-control study. Body mass index and waist circumference were measured. Serum triglycerides, cholesterol (total, high density lipoprotein, and low density lipoprotein cholesterol) and fasting blood glucose were assayed. Metabolic syndrome has been diagnosed in the presence of at least three of the following criteria: increased waist circumference, high triglycerides, fasting glucose or arterial blood pressure and low high density lipoprotein cholesterol.

Results: The present study reports that infertile men are in poorer health condition compared to fertile men and are more often smokers. The results of this study suggested metabolic syndrome and smoking to be independent risk factor for idiopathic infertility.

Conclusions: Metabolic syndrome and smoking should systematically be checked at the beginning of medical care in infertile males and personal and multifaceted coaching should be proposed to deal jointly with smoking and metabolic disorders.

Trial registration: NCT01093378 ALIFERT. Registered: March 25, 2010.

Keywords: Metabolic syndrome, Male fertility, Smoking

\footnotetext{
* Correspondence: charlotte.dupont@aphp.fr

${ }^{\dagger}$ Charlotte Dupont, Céline Faure contributed equally to this work.

'Sorbonne Université, Saint Antoine Research center, INSERM équipe

Lipodystrophies génétiques et acquisesService de biologie de la

reproduction-CECOS, AP-H, Hôpital Tenon, 4 rue de la Chine, 75020 Paris,

France

Full list of author information is available at the end of the article
}

(c) The Author(s). 2019 Open Access This article is distributed under the terms of the Creative Commons Attribution 4.0 International License (http://creativecommons.org/licenses/by/4.0/), which permits unrestricted use, distribution, and reproduction in any medium, provided you give appropriate credit to the original author(s) and the source, provide a link to the Creative Commons license, and indicate if changes were made. The Creative Commons Public Domain Dedication waiver (http://creativecommons.org/publicdomain/zero/1.0/) applies to the data made available in this article, unless otherwise stated. 


\section{Résumé}

Contexte général: Le surpoids et l'obésité sont connus pour avoir un impact sur la fertilité masculine et sont souvent associés à l'obésité abdominale et aux désordres métaboliques. L'association entre l'obésité abdominale ou le syndrome métabolique et les fonctions de reproduction masculine n'est. pas totalement élucidé. De plus, de nombreux facteurs confondants peuvent interférer avec la fertilité masculine. Ainsi, le tabac est. connu pour altérer les paramètres spermatiques et des mécanismes complexes lient le tabagisme au syndrome métabolique. L'objectif principal de cette étude est. d'étudier l'association potentielle entre le syndrome métabolique et l'infertilité idiopathique masculine, compte tenu du statut tabagique.

Matériel et méthodes: Les données de cette étude portent sur des hommes de moins de 45 ans infertiles $(n=96)$ et fertiles $(n=100)$ qui ont été recrutés dans le cadre de l'étude cas-témoins ALIFERT. L'indice de masse corporelle et le tour de taille ont été mesurés. Les triglycérides sériques, le cholestérol (total, high density lipoprotein, low density lipoprotein) et la glycémie à jeun ont été analysés. Le syndrome métabolique a été diagnostiqué en présence d'au moins trois des critères suivants: un tour de taille accru, des triglycérides élevés, une glycémie à jeun ou une tension artérielle élevée et un faible taux de cholestérol « high density lipoprotein ».

Résultats: Cette étude rapporte que les hommes infertiles sont en moins bonne santé que les hommes fertiles et sont plus souvent des fumeurs. Les résultats de cette étude suggèrent que le syndrome métabolique et le tabagisme sont des facteurs de risque indépendants de l'infertilité idiopathique.

Conclusions: Le syndrome métabolique et le tabagisme devraient être systématiquement contrôlés au début des soins médicaux chez les hommes infertiles et un accompagnement personnel et multidisciplinaire devrait être proposé pour traiter conjointement le tabagisme et les troubles du métabolisme.

Mots clés: Syndrome métabolique, Fertilité masculine, Tabagisme

\section{Introduction}

The decline of sperm parameters has been noticed by health care professionals for several years. A meta-analysis has shown that sperm concentration decreased by $52.4 \%$ between 1973 and 2011 [1]. It has been hypothesized that this reduction could be associated with the environment and various factors that affect lifestyle, such as exposure to pollution, radiation, high temperatures, and environmental toxicants. Endocrine disrupters in the air, in food, in drinking water, and in cosmetics have also been associated with sperm quality alterations [2]. Furthermore, lifestyle factors that may compromise male gamete production include tobacco, inadequate diet, lack of physical activity, overweight, obesity, and metabolic syndrome [3]. In particular, the association between changes in sperm characteristics and lifestyle factors is of interest because of the reversibility of those factors and the possibility of acting upon them [4].

Overweight and obesity are documented health concerns worldwide, and cohort studies have linked excess body mass index (BMI) with infertility in both males and females [5]. Several studies [6-8] and a meta-analysis [9] have highlighted semen parameter alterations, especially the decrease in sperm count in overweight and obese subjects. An association between obesity and altered sperm DNA integrity has also been suspected [10].

Given its association with fat accumulation, BMI has commonly been used as a proxy to assess body corpulence, but BMI has traditionally not allowed for the discrimination between subcutaneous and visceral fat. The location of body fat has also been shown to be associated with the development of comorbidities in obese individuals. Therefore, excess fat in specific locations of the body might be a more accurate marker of disease than overall BMI [11]. Abdominal obesity is one component of the metabolic syndrome. Metabolic syndrome is defined as the combination of at least three factors including high waist circumference, high triglycerides, high glycaemia, high blood pressure, and low high-density lipoprotein (HDL) cholesterol [12]. The association between abdominal obesity or metabolic syndrome and male reproduction has not been fully investigated to date, but negative associations with reproductive hormones and semen have been previously suggested, although not proven $[3,13-15]$. Some studies have reported an impact of the metabolic syndrome on sperm parameters or hormone balance [16]. Nevertheless, there remains controversy [17], which may partly be explained by the heterogeneity of the phenotypes of the metabolic syndrome and its different definitions.

Smoking has been demonstrated to have detrimental effects on human health [18]. Besides cardiovascular and carcinogenic effects, smoking also challenges both male and female reproductive functions [19, 20]. In males, 
several studies and a meta-analysis have shown a negative association of smoking with semen parameters $[21,22]$, but less is known about a potential association with male fertility [23].

Although weight gain after smoking cessation has also been reported [24, 25], a few studies have indicated that smoking increases the risk of metabolic syndrome and abdominal obesity through various mechanisms [26-28]. Smoking has been associated with higher body weight and metabolic disorders [29]. In addition, smoking cessation may improve metabolic parameters [26]. Phenomena linking smoking with metabolic syndrome are therefore complex.

The main objective of this study was to investigate the potential association of metabolic syndrome with male idiopathic infertility given smoking status.

\section{Materials and methods}

\section{Patients}

The data of this study concerned infertile $(n=96)$ and fertile $(n=100)$ men younger than 45 years of age who were recruited in the ALIFERT case-control study between September 2009 and December 2013 [30]. The ALIFERT study was designed to assess the association between lifestyle factors and idiopathic infertility in couples (National biomedical research ID no. P071224; ethics committee approval ('Comité de Protection des Personnes') ID no. AOM 2009-A00256-51; NEudra CT ID no. 08180; clinicaltrials.gov ID no. NCT01093378).

Idiopathic or unexplained infertility may be defined by a lack of diagnosis made in couples who failed to conceived after one or two years of unprotected sexual intercourse [31]. It may impact 30 to $40 \%$ of infertile couples [32]. Standard investigation protocol does not provide a diagnosis to explain the infertility. In men, semen analysis is usually performed. It is important to study idiopathic infertility, indeed: even if no cause is clearly identified, the environment and lifestyle could explain it. A better understanding of the origin of the disorder should help in managing infertile couples.

The study group consisted of infertile male partners of couples attending four infertility centres in France, as follows: the Jean Verdier Hospital assisted reproductive Technology (ART) centre, Bondy; the Cochin Hospital ART centre, Paris; the Hôpital Nord ART centre, Saint Etienne; and the Polyclinique de Navarre ART centre, Pau. Study participants were recruited after an initial infertility check-up. Semen analysis for conventional parameters and a semen culture were performed. Medical examination was performed if necessary and medical history was reported. Subject eligibility criteria were (1) primary idiopathic infertility lasting longer than 12 months; (2) age younger than 45 years; (3) no severe oligozoospermia (<5 million/mL); (4) no alterations of the male reproductive organs such as undescended testis, varicocele, or infection; (5) no female factors of infertility; (6) a female partner age of younger than 38 years; and (7) the provision of written informed consent.

The control group consisted of fertile male volunteers recruited from the general healthy population in the areas of the participating centres. Inclusion criteria for this group were (1) a spontaneously conceived child under two years of age, (2) time to pregnancy of less than 12 months, (3) age younger than 45 years, (4) a female partner age of younger than 38 years, and (5) the provision of written informed consent. Members of the control group did not undergo clinical examination or semen parameter analysis before inclusion; however, they were asked about their medical history.

All participants were Caucasians. Infertile and fertile males with current known or previous metabolic or digestive disease were not included.

\section{Assessments}

All study and control subjects were assessed by the same trained investigator using the same calibrated devices.

\section{Anthropometric assessments}

Height, weight (Tanita BC-420MA analyser), and waist circumference at the narrowest point between the lower border of the ribs and the iliac crest were evaluated.

\section{Blood samples and analyses}

Blood samples were collected after a 12-h fasting period. HDL cholesterol, low-density lipoprotein (LDL) cholesterol, triglycerides, and glucose concentrations were instantly measured by standardized methods after centrifugation in the hospitals' biology laboratories.

\section{Blood pressure assessment}

Systolic and diastolic blood pressures were measured using a sphygmomanometer cuff around the patient's arm after five minutes of bed rest in a supine position. The systolic and diastolic blood pressure measurements were the respective means of their right and left values.

\section{Metabolic syndrome definition}

Metabolic syndrome was diagnosed in the presence of at least three of the following criteria: waist circumference of more than $92 \mathrm{~cm}$, triglycerides of $150 \mathrm{mg} / \mathrm{dL} / 1.7$ $\mathrm{mmol} / \mathrm{L}$ or more, HDL cholesterol of less than $40 \mathrm{mg} / \mathrm{dL}$ / $1.0 \mathrm{mmol} / \mathrm{L}$, fasting glucose of $100 \mathrm{mg} / \mathrm{dL} / 5.6 \mathrm{mmol} / \mathrm{L}$ or more, and arterial blood pressure of $130 / 85 \mathrm{mmHg}$ or higher [12].

\section{Smoking status}

Patients reported the number of cigarettes smoked per day and were categorized as a smoker if they smoked 
one or more cigarettes per day and as a nonsmoker if they did not smoke at all. Exhaled carbon monoxide (CO) was measured in parts per million ( $\mathrm{ppm}$ ) as a supportive indicator with the underlying assumption that exhaled carbon monoxide (CO) in smokers [33] is higher than that in nonsmokers. Exhaled $\mathrm{CO}$ measurement was performed by having subjects exhale completely and then inhale fully in open air, holding their breath for 10 $\mathrm{s}$, and then exhaling completely into a portable $\mathrm{CO}$ monitor (Tabataba analyser; FIM Medical, Villeurbanne, France) [33].

\section{Statistical analyses}

Data were summarized using means and standard deviations. The following test plan was applied: (1) differences between infertile and fertile males (t-test), (2) association between smoking and metabolic syndrome (Fisher's exact test), and (3) association between fertility as a dependent variable and both metabolic syndrome and smoking as independent variables (logistic regression). Bonferroni correction was applied to cap overall type I error to $5 \%$ when comparing fertility, metabolic syndrome, and smoking, respectively, between the two groups, thus resulting in a type I error of $1.7 \%$ per test.

\section{Results}

\section{Population description}

No statistical differences were found between infertile and fertile males in term of age, total cholesterol, LDL cholesterol, and triglyceride levels. Also, blood pressures were not significantly different.

However, significant differences did include a higher BMI in the infertile group versus the control group $\left[25.9 \mathrm{~kg} / \mathrm{m}^{2}, 95 \%\right.$ confidence interval (CI): $25.0-26.7$ vs. 23.9, 95\% CI: 23.4-24.5; $p=0.00020$ ] as well as a higher waist circumference $(91.5 \mathrm{~cm}, 95 \%$ CI: $89.3-93.8$ vs. 86.1, 95\% CI: 84.7-87.6; $p<0.0001)$, a higher fasting blood glucose $(5.0 \mathrm{mmol} / \mathrm{L}, 95 \% \mathrm{CI}: 4.8-5.1$ vs. $4.3,95 \%$
CI: 4.1-4.5; $\mathrm{p}<0.0001)$, and a lower HDL cholesterol levels $(1.25 \mathrm{mmol} / \mathrm{L}, 95 \%$ CI: $1.18-1.33$ vs. $1.38 \mathrm{mmol} / \mathrm{L}$, 95\% CI: $1.32-1.44 ; p<0.008$ ) (Table 1).

\section{Metabolic syndrome and smoking}

Both metabolic syndrome and smoking were found to be more frequent in infertile than in fertile males (Table 2), as follows: metabolic syndrome [17/95 (17.9, 95\% CI: $10.8-27.1 \%)$ vs. $6 / 99$ (6.1, 95\% CI: $2.3-12.7 \%)$; Fisher's exact test $p=0.014$ ] and smoking [27/94 $(28.7,95 \% \mathrm{CI}$ : 19.9-39.0\%) vs. $14 / 99$ (14.1, 95\% CI: 8.0-22.6\%); Fisher's exact test $\mathrm{p}=0.014 \mathrm{]}$. Smoking status was not significantly different between males with vs. without metabolic syndrome [7/22 (31.8\%, 95 CI: $13.9-54.9 \%)$ vs. $34 / 170$ (20, 95\% CI: 14.3-26.8\%); Fisher's exact test $p=0.27$ ].

Logistic regression confirmed the absence of an interaction between metabolic syndrome and smoking.

Exhaled CO was significantly higher in smokers $(9.2$ ppm, 95\% CI: 7.2-11.1) than in nonsmokers (3.4 ppm, 95\% CI: 3.1-3.7; $p<0.0001)$.

\section{Discussion}

The strengths of the present study are: (1) comparable infertile and fertile control groups, with respect to most variables other than the study variables; (2) the availability of data in the fertile control group, and (3) assessments by the same trained investigator using the same calibrated devices so as to minimize observation bias. A weakness is the fact that the study sample was identified through a demand for medical assistance, whereas the control population was not, thus causing potential participation bias.

Another limitation was the self-reporting of tobacco consumption, which may be underestimated by some men. The assessment of exhaled $\mathrm{CO}$ was intended to support self-reporting, but exhaled $\mathrm{CO}$ can be influenced by passive smoking and prolonged exposure to a polluted environment [34] so that the level of exhaled

Table 1 Comparison of anthropometric, metabolic parameters and exhaled CO between subfertile and fertile men

\begin{tabular}{|c|c|c|c|}
\hline & Subertile $(n=96)$ & Fertile $(n=100)$ & $p$ \\
\hline Age & $33.3[32.2,34.3]$ & $34.4[33.7,35.1]$ & NS \\
\hline BMI (Kg.m-2) & $25.9[25.0,26.7]$ & $23.9[23.4,24.5]$ & 0.0002 \\
\hline Waist circumference (cm) & $91.5[89.3,93.8]$ & $86.1[84.7,87.6]$ & 0.0001 \\
\hline Fasting blood glucose (mmol/l) & $5.0[4.8,5.1]$ & $4.3[4.1,4.5]$ & $<0.0001$ \\
\hline Total cholesterol (mmol/l) & $5.2[5.01,5.40]$ & $5.2[5.02,5.38]$ & NS \\
\hline HDL cholesterol (mmol/l) & $1.25[1.18,1.33]$ & $1.38[1.32,1.44]$ & $<0.008$ \\
\hline LDL cholesterol (mmol/l) & $3.28[3.09,3.47]$ & $3.24[3.06,3.41]$ & NS \\
\hline Triglycerides (mmol/l) & $1.42[1.23,1.62]$ & $1.20[1.06,1.33]$ & NS \\
\hline Systolic blood pressure (mmHg) & $126[124,129]$ & $126[124,128]$ & NS \\
\hline Diastolic blood pressure $(\mathrm{mmHg})$ & $81[79,83]$ & $80[79,82]$ & NS \\
\hline
\end{tabular}

Data reported as mean and 95\% Cl (confidence interval). BMI (body mass index), HDL (high density lipoprotein), LDL (low density lipoprotein) 
Table 2 Proportion of men with metabolic syndrome and smokers between the groups of subfertile and fertile men

\begin{tabular}{llll}
\hline & Subertile $(\mathrm{n}=96)$ & Fertile $(n=99)$ & $\mathrm{p}$ \\
\hline Metabolic syndrome $(\%, \mathrm{Cl})$ & $17.9[10.0,25.7]$ & $6.1[1.3,10.8]$ & 0.0115 \\
Smokers $(\%, \mathrm{Cl})$ & $28.7[19.4,38.0]$ & $14.1[7.2,21.1]$ & 0.014 \\
\hline $\mathrm{Cl}$ (confidence interval) & & &
\end{tabular}

$\mathrm{CO}$ does not necessarily accurately reflect the amount of smoking done by a subject.

Previous studies have separately analysed the association between semen parameters and abdominal obesity or metabolic syndrome on the one hand and between semen parameters and smoking on the other. Many of these studies suggested a negative impact of abdominal obesity or metabolic syndrome on semen parameters $[3,13,14]$. However, they did not assess male fertility. Other studies have highlighted the negative impact of smoking on semen parameters [21].

The mechanisms involved in these phenomena are complex and multifactorial. Overweightness and obesity have been known for a long time to have a negative impact on conventional and nonconventional semen parameters [35]. Hormonal disorders, systemic inflammation, oxidative stress, and scrotal temperature increase related to obesity are involved in the observed effects. However, it is important to consider the comorbidities associated with obesity, which can also play a critical role. For example, diabetes mellitus may alter semen parameters and male fertility through various mechanisms [36]. There is more evidence that obesity, metabolic disorders, and diabetes mellitus decrease serum testosterone levels. This action may be associated with a defect in Leydig cells [36]. Furthermore, obesity and metabolic disorders are associated with a decrease in androgen production and an increase in aromatase activity as linked to excess adipose tissue. Insulin resistance is responsible for a decrease in sex hormone-binding globulin levels. The consequences are a decrease in plasma testosterone levels and an increase in estradiolemia. Feedback from the hypothalamic-pituitary-gonadal axis is therefore disrupted, leading to hypogonadism. The functions of Sertoli cells are therefore impacted and sperm production is altered.

The originality of the present case-control study was to jointly compare anthropometric and metabolic parameters and smoking in the male partners of idiopathic infertile couples and fertile couples, respectively. The results of this study suggest metabolic syndrome and smoking to be independent risk factors for idiopathic infertility.

Few studies so far have assessed the effect of smoking cessation on semen parameters, hormonal status [37], male fertility, and changes in sexual dysfunction [38, 39].

Nicotine may have a direct negative effect on sperm quality [40], and smoking is understood to alter sperm DNA integrity and induce sperm apoptosis [41].
The results of these previous studies support the need to encourage smoking cessation among infertile men. However, it is important to anticipate weight gain after tobacco cessation [42], given that weight gain can be associated with metabolic disorders and overweightness and obesity, which are known to impact male fertility. While previously published studies found an increased risk of metabolic syndrome in active smokers, the current study was not able to find a significant effect, although we found nonsignificantly identified higher rates of metabolic syndrome in smokers $[26,27]$.

It is widely recognized that nutritional management and increased physical activity can improve cardiovascular comorbidities associated with the metabolic syndrome [43], but to our knowledge no data are available about the impact of lifestyle interventions on reproductive functions in the case of metabolic disorders or metabolic syndrome.

Several studies have shown an improvement in the hormonal balance and erectile function of obese patients after weight loss [44-46]. However, the impact of weight loss on sperm parameters has only been investigated in a limited fashion to date. An improvement in sperm parameters after weight loss has been reported in two studies [45, 47]. Additionally, it has been previously noted in six men with abdominal obesity that abdominal fat loss led to an improvement of sperm DNA integrity linked to an oxidative stress decrease and an antioxidant protection increase in seminal plasma. All female partners became pregnant following the lifestyle intervention [4].

The results of our study suggest that personal and multifaceted coaching should be proposed to deal jointly with smoking and metabolic disorders through nutritional improvement, physical activity, and treatments for high blood pressure and diabetes mellitus. The completion of further prospective interventional randomized controlled trials would be relevant to quantify the benefit of such an approach.

For greater efficiency, young men should be informed about the effects of metabolic syndrome and smoking on fertility as soon as possible. They should strive to improve their lifestyle before they face difficulties with conceiving a child.

Others environmental effects that were not assessed in this study are of importance and may challenge male fertility. Poor lifestyle can also be associated with excessive alcohol consumption, and this can have repercussions on male fertility [48]. Furthermore, men with metabolic disorders and, in particular, dyslipidaemia, may be treated with statins that may reduce testosterone levels and interfere with reproductive functions [49]. Finally, exposure to other environmental toxins such as pollution or mobile phone radiation [50] may be confounding factors. 


\section{Conclusion}

The present study reports that infertile men demonstrate a poorer health condition as compared with fertile men and are more often smokers. Metabolic syndrome and tobacco in men appear as significant and independent risks factors for idiopathic infertility. Health care professionals should be aware of this phenomenon and risks factors should systematically be checked at the beginning of medical care, considering that adverse consequences may be reversible or even preventable.

\section{Abbreviations}

ART: Assisted reproductive technology; BMI: Body mass index; Cl: Confidence interval; HDL: High density lipoprotein; LDL: Low density lipoprotein

\begin{abstract}
Acknowledgements
The authors want to acknowledge the Alifert Collaborative Group: Isabelle Aknin: Unité fonctionnelle de biologie de la reproduction, histologie embryologie - cytogénétique, hôpital Nord, Saint-Étienne, France; Isabelle Cedrin-Durnerin: Service de Médecine de la Reproduction, Hôpital Jean Verdier, APHP, Bondy, France; Steven Cens, Centre d'AMP de PAU, Polyclinique de Navarre, Pau, France; Pascale Chavatte-Palmer: INRA, UMR1198 Biologie du Développement et Reproduction, Jouy en Josas, France; Serge Hercberg: EREN, INSERM U557; INRA; CNAM; Université Paris 13, CRNH IdF, 93017 Bobigny, France; Khaled Pocate: Service d'Histologie-EmbryologieBiologie de la Reproduction, Hôpital Cochin APHP, Paris, France; Nathalie Sermondade: Service de biologie de la reproduction-CECOS, Hôpital Tenon, APHP, Paris, France; Claude Uthurriague, Centre d'AMP de PAU, Polyclinique de Navarre, Pau; Jean-Philippe Wolf: Service d'Histologie-Embryologie-Biologie de la Reproduction, Hôpital Cochin, APHP, Paris, France.

The authors want to acknowledge Ruben Rico, Céline and Luke Edinburgh involved in the paper review.
\end{abstract}

\section{Funding}

Disclosure statement: Financial support: this study was supported by French national biomedical research P071224 ALIFERT.

\section{Availability of data and materials}

Data are the property of the Public Assistance - Paris Hospitals [Assistance Publique - Hôpitaux de Paris (AP-HP)] that does not authorize as a promoter the sharing of data without a contract. Consultation by the editorial board or interested researchers may nevertheless be considered.

\section{Authors' contributions}

CD, CF participated in the study conception and design, in patients recruitment, data acquisition, interpretation and analysis, and drafting of the manuscript. FD and BG participated in study design, performed statistical analysis and participated in critical revision of the manuscript for intellectual content. SC participated in study conception and design, in patient recruitment and critical revisions of the manuscript for intellectual content. $\mathrm{RL}$ participated in study conception and design, interpretation of data, critical revision of the manuscript for intellectual content and supervised the study. The collaborators of the ALIFERT collaborative group participated in study design and were involved in patients' recruitment. All authors read and approved the final manuscript.

\section{Ethics approval and consent to participate}

The ethics committee ("Comité de Protection des Personnes") approved the study. ALIFERT study (national biomedical research P071224/AOM 08180:NEudra CT 2009-A00256-51/clinical trials NCT01093378). All the participants signed a written informed consent.

CPP Ile de France, Numéro de dossier: 2012-nov-13076.

\section{Consent for publication}

Not applicable.

\section{Competing interests}

All authors declare no competing financial interests and consent for publication.

\section{Publisher's Note}

Springer Nature remains neutral with regard to jurisdictional claims in published maps and institutional affiliations.

\section{Author details}

'Sorbonne Université, Saint Antoine Research center, INSERM équipe Lipodystrophies génétiques et acquisesService de biologie de la reproduction-CECOS, AP-H, Hôpital Tenon, 4 rue de la Chine, 75020 Paris, France. ${ }^{2}$ AP-HP, Hôpital Tenon, service de biologie de la reproduction CECOS, Paris, France. ${ }^{3}$ Université Paris Descartes, Paris, France. ${ }^{4}$ APHP, Service de nutrition, Hôpital européen Georges-Pompidou, Paris, France.

Received: 17 December 2018 Accepted: 5 May 2019

Published online: 01 July 2019

\section{References}

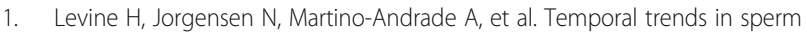
count: a systematic review and meta-regression analysis. Hum Reprod Update. 2017;23(6):646-59.

2. Sharpe RM, Irvine DS. How strong is the evidence of a link between environmental chemicals and adverse effects on human reproductive health? BMJ. 2004;328(7437):447-51.

3. Michalakis K, Mintziori G, Kaprara A, Tarlatzis BC, Goulis DG. The complex interaction between obesity, metabolic syndrome and reproductive axis: a narrative review. Metabolism. 2013;62(4):457-78.

4. Faure C, Dupont C, Baraibar MA, et al. In subfertile couple, abdominal fat loss in men is associated with improvement of sperm quality and pregnancy: a case-series. PLoS One. 2014;9(2):e86300.

5. Ramlau-Hansen CH, Thulstrup AM, Nohr EA, Bonde JP, Sorensen TI, Olsen J. Subfecundity in overweight and obese couples. Hum Reprod. 2007;22(6):1634-7.

6. Belloc S, Cohen-Bacrie M, Amar E, et al. High body mass index has a deleterious effect on semen parameters except morphology: results from a large cohort study. Fertil Steril. 2014;102(5):1268-73.

7. Chavarro JE, Toth TL, Wright DL, Meeker JD, Hauser R. Body mass index in relation to semen quality, sperm DNA integrity, and serum reproductive hormone levels among men attending an infertility clinic. Fertil Steril. 2010;93(7):2222-31.

8. Kort HI, Massey JB, Elsner CW, et al. Impact of body mass index values on sperm quantity and quality. J Androl. 2006;27(3):450-2.

9. Sermondade $\mathrm{N}$, Faure $\mathrm{C}$, Fezeu $\mathrm{L}$, et al. BMI in relation to sperm count: an updated systematic review and collaborative meta-analysis. Hum Reprod Update. 2013;19(3):221-31.

10. Dupont C, Faure C, Sermondade N, et al. Obesity leads to higher risk of sperm DNA damage in infertile patients. Asian J Androl. 2013;15(5):622-5.

11. Onat A, Avci GS, Barlan MM, Uyarel H, Uzunlar B, Sansoy V. Measures of abdominal obesity assessed for visceral adiposity and relation to coronary risk. Int J Obes Relat Metab Disord. 2004;28(8):1018-25.

12. Alberti KG, Eckel RH, Grundy SM, et al. Harmonizing the metabolic syndrome: a joint interim statement of the international diabetes federation task force on epidemiology and prevention; National Heart, Lung, and Blood Institute; American Heart Association; world heart federation; international atherosclerosis society; and International Association for the Study of obesity. Circulation. 2009;120(16):1640-5.

13. Leisegang K, Udodong A, Bouic PJ, Henkel RR. Effect of the metabolic syndrome on male reproductive function: a case-controlled pilot study. Andrologia. 2014;46(2):167-76.

14. Ventimiglia E, Capogrosso P, Colicchia M, et al. Metabolic syndrome in white European men presenting for primary couple's infertility: investigation of the clinical and reproductive burden. Andrology. 2016;4(5):944-51.

15. Lu JC, Jing J, Yao Q, et al. Relationship between lipids levels of serum and seminal plasma and semen parameters in 631 Chinese subfertile men. PLoS One. 2016;11(1):e0146304.

16. Leisegang K, Bouic PJ, Menkveld R, Henkel RR. Obesity is associated with increased seminal insulin and leptin alongside reduced fertility parameters in a controlled male cohort. Reprod Biol Endocrinol. 2014;12:34. 
17. Pilatz A, Hudemann C, Wolf J, et al. Metabolic syndrome and the seminal cytokine network in morbidly obese males. Andrology. 2017;5(1):23-30.

18. Teo KK, Ounpuu S, Hawken S, et al. Tobacco use and risk of myocardial infarction in 52 countries in the INTERHEART study: a case-control study. Lancet. 2006;368(9536):647-58.

19. Oboni JB, Marques-Vidal P, Bastardot F, Vollenweider P, Waeber G. Impact of smoking on fertility and age of menopause: a population-based assessment. BMJ Open. 2016;6(11):e012015.

20. Sansone A, Di Dato C, de Angelis C, et al. Smoke, alcohol and drug addiction and male fertility. Reprod Biol Endocrinol. 2018;16(1):3

21. Ramlau-Hansen $\mathrm{CH}$, Thulstrup AM, Aggerholm AS, Jensen MS, Toft G, Bonde JP. Is smoking a risk factor for decreased semen quality? A cross-sectional analysis. Hum Reprod. 2007;22(1):188-96.

22. Sharma R, Harlev A, Agarwal A, Esteves SC. Cigarette smoking and semen quality: a new meta-analysis examining the effect of the 2010 World Health Organization Laboratory methods for the examination of human semen. Eur Urol. 2016;70(4):635-45.

23. Harlev A, Agarwal A, Gunes SO, Shetty A, du Plessis SS. Smoking and male infertility: an evidence-based review. World J Mens Health. 2015;33(3):143-60.

24. Krukowski RA, Bursac Z, Little MA, Klesges RC. The relationship between body mass index and post-cessation weight gain in the year after quitting smoking: a cross-sectional study. PLoS One. 2016;11(3):e0151290.

25. Aubin HJ, Farley A, Lycett D, Lahmek P, Aveyard P. Weight gain in smokers after quitting cigarettes: meta-analysis. BMJ. 2012;345:e4439.

26. Sun K, Liu J, Ning G. Active smoking and risk of metabolic syndrome: a meta-analysis of prospective studies. PLoS One. 2012;7(10):e47791.

27. Slagter SN, van Vliet-Ostaptchouk JV, Vonk JM, et al. Associations between smoking, components of metabolic syndrome and lipoprotein particle size. BMC Med. 2013;11:195

28. Clair C, Chiolero A, Faeh D, et al. Dose-dependent positive association between cigarette smoking, abdominal obesity and body fat: cross-sectional data from a population-based survey. BMC Public Health. 2011;11:23.

29. de Oliveira Fontes Gasperin L, Neuberger M, Tichy A, Moshammer H. Crosssectional association between cigarette smoking and abdominal obesity among Austrian bank employees. BMJ Open. 2014:4(7):e004899.

30. Faure C, Dupont C, Chavatte-Palmer P, Gautier B, Levy R, Group AC. Are semen parameters related to birth weight? Fertil Steril. 2015;103(1):6-10.

31. Ray A, Shah A, Gudi A, Homburg R. Unexplained infertility: an update and review of practice. Reprod BioMed Online. 2012;24(6):591-602.

32. Smith S, Pfeifer SM, Collins JA. Diagnosis and management of female infertility. JAMA. 2003;290(13):1767-70.

33. Deveci SE, Deveci F, Acik Y, Ozan AT. The measurement of exhaled carbon monoxide in healthy smokers and non-smokers. Respir Med. 2004;98(6):551-6.

34. Maga M, Janik MK, Wachsmann A, et al. Influence of air pollution on exhaled carbon monoxide levels in smokers and non-smokers. A prospective cross-sectional study. Environ Res. 2017;152:496-502.

35. La Vignera S, Condorelli RA, Vicari E, Calogero AE. Negative effect of increased body weight on sperm conventional and nonconventional flow cytometric sperm parameters. J Androl. 2012;33(1):53-8.

36. La Vignera S, Condorelli R, Vicari E, D'Agata R, Calogero AE. Diabetes mellitus and sperm parameters. J Androl. 2012;33(2):145-53.

37. Trummer $\mathrm{H}$, Habermann $\mathrm{H}$, Haas J, Pummer K. The impact of cigarette smoking on human semen parameters and hormones. Hum Reprod. 2002;17(6):1554-9.

38. Lotti F, Corona G, Vitale P, et al. Current smoking is associated with lower seminal vesicles and ejaculate volume, despite higher testosterone levels, in male subjects of infertile couples. Hum Reprod. 2015;30(3):590-602.

39. Camacho EM, Huhtaniemi IT, O'Neill TW, et al. Age-associated changes in hypothalamic-pituitary-testicular function in middle-aged and older men are modified by weight change and lifestyle factors: longitudinal results from the European male ageing study. Eur J Endocrinol. 2013;168(3):445-55.

40. Condorelli RA, La Vignera S, Giacone F, et al. In vitro effects of nicotine on sperm motility and bio-functional flow cytometry sperm parameters. Int J Immunopathol Pharmacol. 2013;26(3):739-46.

41. Calogero A, Polosa R, Perdichizzi A, et al. Cigarette smoke extract immobilizes human spermatozoa and induces sperm apoptosis. Reprod BioMed Online. 2009;19(4):564-71.

42. Tian J, Venn A, Otahal P, Gall S. The association between quitting smoking and weight gain: a systemic review and meta-analysis of prospective cohort studies. Obes Rev. 2015;16(10):883-901.
43. Sperling LS, Mechanick JI, Neeland IJ, et al. The CardioMetabolic health Alliance: working toward a new care model for the metabolic syndrome. J Am Coll Cardiol. 2015;66(9):1050-67.

44. Kaukua J, Pekkarinen T, Sane T, Mustajoki P. Sex hormones and sexual function in obese men losing weight. Obes Res. 2003;11(6):689-94.

45. Hakonsen LB, Thulstrup AM, Aggerholm AS, et al. Does weight loss improve semen quality and reproductive hormones? Results from a cohort of severely obese men. Reprod Health. 2011;8:24.

46. Hannan JL, Maio MT, Komolova M, Adams MA. Beneficial impact of exercise and obesity interventions on erectile function and its risk factors. J Sex Med. 2009:6(Suppl 3):254-61.

47. Rafiee B, Morowvat MH, Rahimi-Ghalati N. Comparing the effectiveness of dietary vitamin $\mathrm{C}$ and exercise interventions on fertility parameters in Normal obese men. Urol J. 2016;13(2):2635-9.

48. La Vignera S, Condorelli RA, Balercia G, Vicari E, Calogero AE. Does alcohol have any effect on male reproductive function? A review of literature. Asian J Androl. 2013;15(2):221-5.

49. La Vignera S, Condorelli RA, Vicari E, Calogero AE. Statins and erectile dysfunction: a critical summary of current evidence. J Androl. 2012:33(4):552-8.

50. La Vignera S, Condorelli RA, Vicari E, D'Agata R, Calogero AE. Effects of the exposure to mobile phones on male reproduction: a review of the literature. J Androl. 2012;33(3):350-6.

\section{Ready to submit your research? Choose BMC and benefit from:}

- fast, convenient online submission

- thorough peer review by experienced researchers in your field

- rapid publication on acceptance

- support for research data, including large and complex data types

- gold Open Access which fosters wider collaboration and increased citations

- maximum visibility for your research: over $100 \mathrm{M}$ website views per year

At $\mathrm{BMC}$, research is always in progress.

Learn more biomedcentral.com/submissions 